\title{
Fluoride Determination in Pickling Solution of Stainless Steel by Ion Selective Electrode
}

\author{
Yusuf Yildiz ${ }^{1, ~ *}$, Angela $\mathrm{Jan}^{2}$, Sapan Patel $^{3}$ \\ ${ }^{1}$ Analytical Chemistry Research Department, Complete Analysis Laboratories, New Jersey, USA \\ ${ }^{2}$ Analytical Chemistry Department, Whitehouse Labs/AMRI, New Jersey, USA \\ ${ }^{3}$ Whiting School of Engineering, John Hopkins University, Baltimore, USA \\ Email address: \\ sayatoglu@yahoo.com(Y.Yildiz) \\ ${ }^{*}$ Corresponding author
}

\section{To cite this article:}

Yusuf Yildiz, Angela Jan, Sapan Patel. Fluoride Determination in Pickling Solution of Stainless Steel by Ion Selective Electrode. World Journal of Applied Chemistry. Vol. 3, No. 1, 2018, pp. 28-31. doi: 10.11648/j.wjac.20180301.14

Received: February 23, 2018; Accepted: March 11, 2018; Published: April 9, 2018

\begin{abstract}
The Fluoride Ion Selective Electrode is an ion-selective sensor and will quickly and accurately measure fluoride ion activity rather than concentration in aqueous solutions. Fluoride ion activity depends on the solution total ionic strength and $\mathrm{pH}$, and on fluoride complexing species. Adding an appropriate buffer provides a nearly uniform ionic strength background, adjust $\mathrm{pH}$, and breaks up complexes so that, in effect, the electrode measures concentration. Pickling removes a thin surface layer from the stainless, using an acid solution, which is usually a hydrofluoric acid (HF) and nitric acid $\left(\mathrm{HNO}_{3}\right)$, also called mixed acid. In this study, fluoride ion strength has been measured of pickling waste water from stainless steel by ion selective electrode. The results met the specification.
\end{abstract}

Keywords: Pickling Stainless Steel Solution, Fluoride, Ion Selective Electrode

\section{Introduction}

Acid Cleaning (Pickling):

Stainless steel is composed of iron (Fe), nickel (Ni), chromium (Cr) and several other minor components. Stainless steel is not resistant to chemical or physical attack. The corrosion resistance of stainless steel depends on the formation of a 'passive surface film' composed of nickel and chromium oxides $\left(\mathrm{Cr}_{2} \mathrm{O}_{3} \& \mathrm{NiO}\right)$. When stainless steel is newly made it is cleaned of oils and greases used in the fabrication process.

Pickling is the most common chemical procedure used to remove oxides and iron contamination. Besides removing the surface layer by controlled corrosion, pickling also selectively removes the least corrosion-resistant areas such as the chromium-depleted zones. Pickling normally involves using an inorganic acid mixture containing nitric acid $\left(\mathrm{HNO}_{3}\right)$, hydrofluoric acid (HF) and, sometimes, also sulfuric acid $\left(\mathrm{H}_{2} \mathrm{SO}_{4}\right)$. Owing to the obvious risk of pitting corrosion, chloride-containing agents such as hydrochloric acid $(\mathrm{HCl})$ must be avoided [1]. Pickling solution also remove contaminants such as ferrous and ferric oxide particles.
Pickling involves metal removal and a charge or dulling in the visual brightness of the metal.

\section{Materials}

\subsection{Apparatus}

1. Magnetic stirrer, with TFE-coated stirring bar

2. Timer

3. Fluoride electrode and ion-selective meter: The following apparatus were used for this study: Fluoride selective electrode, solution dispenser and, Hanna 2215/ISE NH35 meter with $0.1 \mathrm{mV}$ resolution. The Fluoride Ion-Selective Electrode has a solid-state monocrystalline membrane. The electrode is designed for the detection of fluoride ions $\left(\mathrm{F}^{-}\right)$in aqueous solutions and is suitable for use in both field any laboratory applications. Optimum $\mathrm{pH}$ range is 4 to 8 , temperature range is 0 to $80^{\circ} \mathrm{C}$. The fluoride ionselective electrode measures quick and accurately 
fluoride ion activity in aqueous solution [2].

\subsection{Reagents}

1. Pickling (Acid Cleaning) Stainless Steel Solution

2. Stock fluoride solution: Dissolve $221.0 \mathrm{mg}$ anhydrous sodium fluoride (NaF, GFS reagent ACS, min 99.0\%, CAS\# 7681-49-4) in distilled water and diluted to 1000 $\mathrm{ml} ; 1 \mathrm{~mL}=100 \mu \mathrm{g} \mathrm{F}^{-}$Table 1 [3].

3. Sodium Fluoride (second sources for check standard). Certified ACS Powder, 99-100\%. Lot\# 157879, CAS\# 761-49-4. Fisher Chemical

4. Total Ionic Strength Fluoride Buffer solution, $\mathrm{pH}=5.32$ : This solution marketed commercially under the trade name TSIAB [4]. Sufficient buffer for 15-20 determinations can be prepared by mixing with stirring $57 \mathrm{~mL}$ of glacial acetic acid, $58 \mathrm{~g}$ of sodium chloride, 4 $\mathrm{g}$ of cyclohexylaminedinitrilotetraacetic acid, and 500 $\mathrm{mL}$ of distilled water in a 1-L beaker. Cool the contents in a water or ice bath, and carefully add $6 \mathrm{M}$ sodium hydroxide to a $\mathrm{pH}$ of 5.0 to 5.5 . Dilute to $1 \mathrm{~L}$ with water, and store in a plastic bottle [5] [11].

5. Standard fluoride solution (working solution): Dilute $100 \mathrm{~mL}$ stock fluoride solution to $1000 \mathrm{~mL}$ with distilled water; $1.00 \mathrm{~mL}=10.0 \mu \mathrm{g} \mathrm{F}^{-}$

6. Serial Fluoride standards: Into $100 \mathrm{~mL}$ volumetric flasks, put $\mathrm{V} \mathrm{mL}$ ) of $10 \mathrm{mg} / \mathrm{L}$ fluoride standard, quantitatively fill with $\mathrm{D}$. I. water to obtained series standards, $\mathrm{mg} \mathrm{F}^{-} / \mathrm{L}$ (Table2) [3] [8].

7. Deionized water, on the day of use. Water was purified using a Millipore Milli-Q system via a pure water device marked Purelab Option-Q7BP.

All fluoride standard solutions should be stored in high density polyethylene bottles at $4^{\circ} \mathrm{C}[6]$, [7].

Table 1. Preparation of fluoride standard stock solution.

\begin{tabular}{lllll}
\hline Stock std. & $\mathbf{0 . 1 1 0 5 0}$ & $\mathbf{m ~ N a F}(\mathbf{g})$ & $\mathbf{N a}$ & $\mathbf{2 2 . 9 8 9 0}$ \\
\hline Volume & 0.5000 & $\mathrm{~V} \mathrm{~L}$ & $\mathrm{~F}$ & 18.9980 \\
Conc. & 100 & {$\left[\mathrm{~F}^{-}\right] \mathrm{mg} / \mathrm{L}$} & $\mathrm{F} / \mathrm{NaF}$ & 0.4525 \\
Std. & 10 & & $\mathrm{NaF}$ & 41.9970 \\
\hline
\end{tabular}

Table 2. Serial standards for calibration curve.

\begin{tabular}{lll}
\hline Volume of Working Standard Solution $(\mathbf{m L})$ & Diluted to total volume $(\mathbf{m L})$ & Standard $\mathbf{F}^{-}$Concentration $(\mathbf{m g} / \mathbf{L})$ \\
\hline 2.0 & 100 & 0.2 \\
5.0 & 100 & 0.5 \\
10.0 & 100 & 1.0 \\
20.0 & 100 & 2.0 \\
40.0 & 100 & 4.0 \\
\hline
\end{tabular}

\subsection{Installation- Electrode Check}

Remove the protective end cot covering the electrode tip rubber insert covering the filling hole of the reference electrode. Fill the combination electrode with the $4 \mathrm{~N} \mathrm{KCl}$ filling solution. Connect the electrodes to the proper terminals of the meter [9] [10].

Check the operation of the electrode as follows: measure $30.0 \mathrm{~mL}$ of buffer solution $(\mathrm{pH}=5.32)$ in a $100 \mathrm{~mL}$ graduated cylinder. Add DI water to bring to volume to $99.0 \mathrm{~mL}$. Pour the solution into a $400 \mathrm{~mL}$ plastic or Teflon beaker. Set the beaker on a magnetic mixer, put in a stirring bar, and start the mixer. Stir a moderate. Stir both standards and samples at the same rate. Set the meter in the $\mathrm{mV}$ display mode. Immerse the electrode tip in the solution and turn on the meter. Using a new pipet tip add $1.0 \mathrm{~mL}$ of Standard Fluoride Solution $(100 \mathrm{mg} / \mathrm{L})$. Measurements should always be made going from a more dilute to a more concentrated solution. Allow 15 minutes for the meter reading to stabilize. A reading that holds for 3-4 minutes is considered stable. Record the meter reading as $\mathrm{mV}_{1}$. Add second $1.0 \mathrm{~mL}$ portion of Standard Fluoride Solution. When the reading stabilizes record it as $m V_{2}$. Subtract $m V_{2}$ from $m V_{1}$ to get $\Delta E$. Look up the $m V$ difference on the Table 5 to get $\mathrm{mg} \mathrm{F}^{-}$. Interpolate to get a 3 decimal reading. The recovery should be from 0.100 to 0.105 $\mathrm{mg} \mathrm{F}^{-}$[8] [9] [12].

$\mathrm{E}_{1}=40.3 \mathrm{mV}, \mathrm{E}_{2}=22.6 \mathrm{mV}$.

$\Delta \mathrm{E}=40.3-22.6=17.7 \mathrm{mV}$ (From the Table 5, for $17 \mathrm{mV}$ $\left(0.107 \mathrm{mg} \mathrm{F}^{-}\right)$, for $18 \mathrm{mV}\left(0.099 \mathrm{mg} \mathrm{F}^{-}\right)$
Interpolation: $0.107-\frac{17.7-17.0}{18.0-17.0} \times(0.107-0.099)=0.101 \mathrm{mg} \mathrm{F}^{-}$

\subsection{Sample Preparation and Analytical Procedure for Analysis}

For accurate measurement, the standards and the samples should be at the same temperature. Add DI water to a 1 liter volumetric flask to within $1 / 2$ inch from the mark. Accurately pipet $1.0 \mathrm{~mL}$ of Pickling -Acid Cleaning Solution into the volumetric flask. Add DI water to the mark and mix. Pipet a $10.0 \mathrm{~mL}$ of the sample solution into a Teflon beaker, add $30.0 \mathrm{~mL}$ of buffer solution, $60 \mathrm{~mL}$ of DI water. Set the beaker on the mixer, immerse the electrode, stir well and record the stable reading as $m V_{1}$. Add $1.0 \mathrm{~mL}$ portion of Standard Fluoride Solution in excess. When the reading stabilizes (about 3-4 minutes) record the meter reading as $m V_{2}$. Subtract $m V_{2}$ from $m V_{1}$, to get $\Delta \mathrm{E}$. Look up the $\mathrm{mV}$ difference on the Table 6 to get $\operatorname{mg~F}^{-}[2,9]$.

\section{Result and Discussion}

The fluoride electrode is a solid state electrode can be used with a standard calomel reference electrode and almost any modern $\mathrm{pH}$ meter having an expanded millivolt scale. For the best results, the instrument was calibrated every 1-2 hours. Two standard solutions have been used to bracket the concentration range of interest.

Before use, the fluoride ion-selective electrode has been 
calibrated by measuring a series of known standard solutions. For a full calibration, $100 \mathrm{~mL}$ of solutions containing $0.2,0.5,1.0,2.0$, and $4.0 \mathrm{ppm} \mathrm{F}^{-}$must be prepared [9].

Table 3. Calibration Curve Data.

\begin{tabular}{lllll}
\hline & Flouride & & & \\
\hline Stock Sol. & 0.2226 & $\mathrm{~m} \mathrm{NaF}(\mathrm{g})$ & $\mathrm{Na}$ & 22.989 \\
& 1 & $\mathrm{~V} \mathrm{~L}$ & $\mathrm{~F}$ & 18.998 \\
& 100.72 & {$[\mathrm{~F}-] \mathrm{mg} / \mathrm{L}$} & $\mathrm{F} / \mathrm{NaF}$ & 0.4525 \\
Standard & 10.07 & & & \\
Series Std & {$[\mathrm{F}-] \mathrm{mg} / \mathrm{L}$} & $\mathrm{Log}[\mathrm{F}-]$ & $\mathrm{E} / \mathrm{mV}$ & \\
0.2 & 0.201 & -0.6959 & 87.2 & \\
0.5 & 0.504 & -0.2979 & 61.3 & \\
1 & 1.007 & 0.0031 & 48.2 & \\
2 & 2.014 & 0.3041 & 28.5 & \\
4 & 4.029 & 0.6052 & 11.9 & \\
& & $\mathrm{RSQ}:$ & $\mathrm{R} \wedge 2$ & 0.9971 \\
& & $\mathrm{dE} / \mathrm{dlog}[\mathrm{F}]:$ & $\mathrm{m}$ & -57.3217 \\
& & $\mathrm{E}$ for $[\mathrm{F}]=1:$ & $\mathrm{b}$ & 46.4877 \\
\hline
\end{tabular}

Table 4. Ion-Selective Electrode Measurements.

\begin{tabular}{|c|c|c|c|c|}
\hline Identity & $\mathbf{E} / \mathbf{m V}$ & {$[\mathrm{F}-] \mathrm{mg} / \mathrm{L}$} & DF & Corr $[\mathbf{F}-]$ \\
\hline $2.0 \mathrm{mg} / \mathrm{L}$ indep. & 28.6 & 2.051 & 1 & 2.051 \\
\hline $0.2 \mathrm{mg} / \mathrm{L}$ indep. & 87.0 & 0.196 & 1 & 0.196 \\
\hline Water & 166.0 & 0.008 & 1 & 0.008 \\
\hline Pickling sample A & 20.7 & 2.818 & 1 & 2.818 \\
\hline Pickling Sample B & 20.6 & 2.829 & 1 & 2.829 \\
\hline Spiked & 13.2 & 3.808 & 1 & 3.808 \\
\hline Spiked duplicate & 13.2 & 3.808 & 1 & 3.808 \\
\hline \multicolumn{5}{|c|}{ Average results of sample: $2.824 \mathrm{mg} \mathrm{F}^{-} / \mathrm{L}$} \\
\hline \multicolumn{5}{|c|}{ Concentration of Spiking Solution: $100 \mathrm{mg} / \mathrm{L}$} \\
\hline \multicolumn{5}{|c|}{ Sample volume: $10 \mathrm{~mL}$, } \\
\hline \multicolumn{5}{|c|}{ Spiked amount: $1.0 \mathrm{mg} / \mathrm{L}$} \\
\hline$\% \mathrm{R}$ MS & $98.4 \%$ & & & \\
\hline$\%$ R MSD & $98.4 \%$ & & & \\
\hline
\end{tabular}

Calculations

The volume of sample taken for measurement is $1.0 / 1000$ $\mathrm{x} 10.0=0.010 \mathrm{~mL}$, therefore the $\mathrm{F}$ - content of the original sample in $\mathrm{mg} / \mathrm{L}$ is $\mathrm{mg} \mathrm{F}-\mathrm{x} 100,000$. The equivalent weight of $\mathrm{F}^{-}$is $19.0 \mathrm{~g}$ or $19,000 \mathrm{mg}$. The $\mathrm{F}$ - normality of the original pickling sample is then:

Normality of Fluoride $=m g \mathrm{~F}^{-} \frac{100,000}{19,000}$
Table 5. Measurement data of fluoride by ISE.

\begin{tabular}{llllll}
\hline & $\mathbf{E}_{\mathbf{1}}\left(\mathbf{m} \mathbf{V}_{\mathbf{1}}\right)$ & $\mathbf{E}_{\mathbf{2}}\left(\mathbf{m V}_{\mathbf{2}}\right)$ & $\mathbf{\Delta E}$ & $\mathbf{m g} \mathbf{F}-$ & $\mathbf{N ~ o f ~} \mathbf{F}^{-}$ \\
\hline Pickling sample & 40.6 & 19.9 & 20.7 & 0.0815 & 0.43 \\
Duplicate & 40.4 & 19.8 & 20.6 & 0.0820 & 0.43 \\
\hline
\end{tabular}

From the Table 5, for $20.0 \mathrm{mV}$ [0.085 $\left.\mathrm{mg} \mathrm{F}^{-}\right]$, for $21 \mathrm{mV}$ [0.080 $\left.\mathrm{mg} \mathrm{F}^{-}\right]$

Interpolation $=0.085-\frac{20.7-20.0}{21.0-20.0} \times(0.085-0.080)=0.0815$ $\mathrm{mg} \mathrm{F}$

$$
\text { Normality of } \mathrm{F}^{-}=\frac{100,000}{19,000}=0.43 \mathrm{~N}
$$

Spike Recovery Check (accuracy)

Calibration curve was obtained as $\mathrm{E}(\mathrm{mV})$ vs $\log \left[\mathrm{F}^{-}\right]$. Where, $\left[\mathrm{F}^{-}\right]$is $\mathrm{mg} / \mathrm{L}$ and $\log$ is base 10 . Slope $\mathrm{m}$ is $\mathrm{dE} / \mathrm{dlog}$ $\left[\mathrm{F}^{-}\right]$, i.e. the usual $\mathrm{y}=\mathrm{mx}+\mathrm{b}$, and intercept $\mathrm{b}$ is value of $\mathrm{E}$ for $\left[\mathrm{F}^{-}\right]=1 \mathrm{mg} / \mathrm{L}$, i.e. $\mathrm{y}$ intercept for $\mathrm{x}=0$. Expect $\mathrm{R}^{2}$ to be 0.999 or greater, 1.0000 obtained Table 4, and Figure 1.

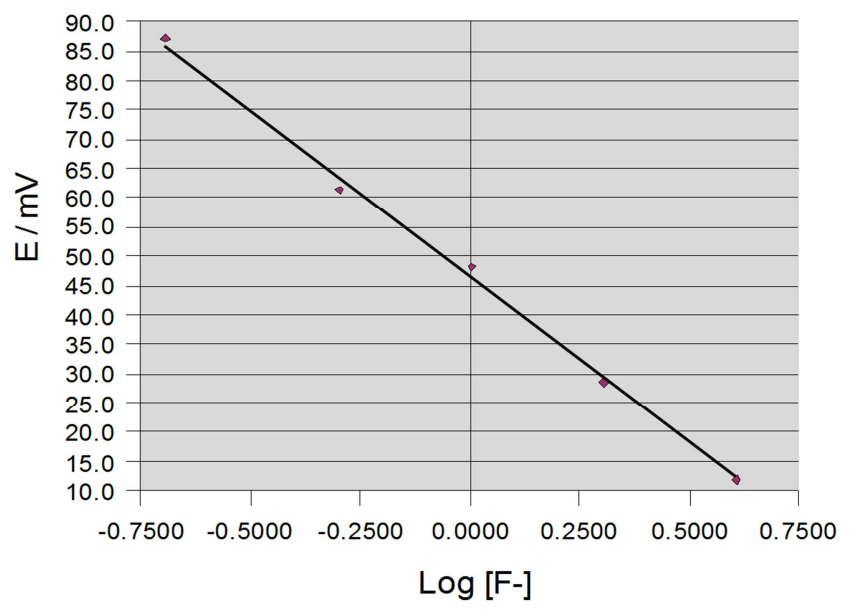

Figure 1. Calibration curve of fluoride.

\section{Conclusions}

The Ion-Selective Electrode Method has been used for determining fluoride in the pickling (Acid Cleaning) Solution of Stainless Steel. The result have been displayed as ppm $(\mathrm{mg} / \mathrm{L})$, and mole/L in solution. The concentration of F- in Pickling (Acid Cleaning) Stainless Steel solution was $0.43 \mathrm{~N}$. The specification range is 0.4 to 0.6 .

The average spiked recovery of fluoride content in pickling solution was $98.4 \%$, RPD was $0.39 \%$ Table 4 .

\section{Appendix}

Table 6. Millivolt Difference and $m g F$

\begin{tabular}{|c|c|c|c|c|c|}
\hline mV Difference & mg F- & mV Difference & mg F- & mV Difference & mg F- \\
\hline 8 & 0.274 & 37 & 0.032 & 66 & 0.0083 \\
\hline 9 & 0.239 & 38 & 0.030 & 67 & 0.0080 \\
\hline 10 & 0.210 & 39 & 0.029 & 68 & 0.0076 \\
\hline 11 & 0.187 & 40 & 0.027 & 69 & 0.0073 \\
\hline 12 & 0.168 & 41 & 0.026 & 70 & 0.0070 \\
\hline 13 & 0.152 & 42 & 0.024 & 71 & 0.0067 \\
\hline 14 & 0.138 & 43 & 0.023 & 72 & 0.0065 \\
\hline 15 & 0.124 & 44 & 0.022 & 73 & 0.0062 \\
\hline
\end{tabular}




\begin{tabular}{llllll}
\hline mV Difference & mg F- & mV Difference & mg F- & mV Difference & mg F- \\
\hline 16 & 0.116 & 45 & 0.021 & 74 & 0.0060 \\
17 & 0.107 & 46 & 0.020 & 75 & 0.0057 \\
18 & 0.099 & 47 & 0.019 & 76 & 0.0055 \\
19 & 0.092 & 48 & 0.018 & 77 & 0.0053 \\
20 & 0.085 & 49 & 0.018 & 78 & 0.0051 \\
21 & 0.080 & 50 & 0.017 & 79 & 0.0049 \\
22 & 0.074 & 51 & 0.016 & 80 & 0.0047 \\
23 & 0.070 & 52 & 0.015 & 81 & 0.0045 \\
24 & 0.065 & 53 & 0.015 & 82 & 0.0043 \\
25 & 0.061 & 54 & 0.014 & 83 & 0.0041 \\
26 & 0.057 & 55 & 0.014 & 84 & 0.0038 \\
27 & 0.054 & 56 & 0.013 & 85 & 0.0031 \\
28 & 0.051 & 57 & 0.013 & 90 & 0.0021 \\
29 & 0.048 & 58 & 0.012 & 100 & 0.0014 \\
30 & 0.045 & 59 & 0.012 & 110 & 0.00094 \\
31 & 0.043 & 60 & 0.011 & 120 & 0.00064 \\
32 & 0.040 & 61 & 0.010 & 130 & 0.00043 \\
33 & 0.038 & 62 & 0.010 & 140 & 0.00029 \\
34 & 0.036 & 63 & 0.0094 & 150 & \\
35 & 0.035 & 64 & 0.0090 & & \\
36 & 0.033 & 65 & 0.087 & & \\
\hline
\end{tabular}

\section{References}

[1] Bohler Welding Nordic AB. Pickling Handbook. Surface Treatment of Stainless Steel.

[2] Technical Specification for the Fluoride Ion-Selective Electrode (ELIT 82221).

[3] Y. Yildiz; Determination of Fluoride in tri-calcium phosphate (TCP) by Ion-Selective Electrode. International Journal of Development Research, Vol. 5, issue: 10, pp: 5704-5706, October, 2015.

[4] Orion Research, Boston, MA.

[5] Skoog/West/Holber, Analytical Chemistry an Introduction, Sixth Edition. Saunders Golden Sunburst Series. 1993, USA.

[6] Prem N. Vijan and Baverly Aider, Determination of fluoride in vegetable by ion-selective electrode. American laboratory, December 1984.

[7] Dionex, Application Note 209. Determination of Fluoride in Acidulated Phosphate Topical Solutions using reagent-Free Ion Chromatography.

[8] Method for Determining the Concentration of Fluoride $\left(\mathrm{F}^{-}\right)$ in Aqueous Solutions. NICO 2000. ELIT Brand Electrochemical Sensors.

[9] Edens G. and Yildiz Y. Standard method for Determination of Fluoride in ARDE Pickling sample. Complete Analysis Laboratories, June 18, 2010. New Jersey, USA.

[10] Fluoride Combination Ion Selective Electrode, Accument. Cat No: 13-620-528\& 13-620-529 Published: 03/94.

[11] Standard Methods for the Examination of Water \&Wastewater, $21^{\text {st }}$ Edition 2005. 4500-F-C Ion-Selective Electrode Method p: 4-84.

[12] J. R. Sherman, Standard Method for Determination of Fluoride. Arde, Inc. New Jersey. 9-18- 2006. 